\title{
Seasonality in Consumption: An Economic Analysis of the Alimentary Patterns in Greece (1957 -2005)
}

\author{
Ioannis Sotiropoulos \\ Department of Finance and Auditing, TEI of Epirus, Greece \\ E-mail: sotiropoulosioan@yahoo.gr
}

Georgios Georgakopoulos

Amsterdam Business School, University of Amsterdam, The Netherlands

E-mail: g.georgakopoulos@uva.nl

Konstantina Pendaraki

Department of Business Administration of Food and Agricultural Enterprises

University of Ioannina, Greece

E-mail: dpendara@cc.uoi.gr

JEL Classification: M31, E21, Q11.

\begin{abstract}
This paper attempts to explore financial expenditure of households in post-war Greece (1957-2005) in our endeavour to describe annual seasonality patterns of food consumption. Agricultural/industrial, animal/plant-based, in-house/away-from-home alimentation features are examined in an effort to understand and qualitatively categorise the evolution and progression of food consumption over time. Our analysis is performed presenting descriptive statistics and data gathered from the "Household Budget Surveys" (H.B.S.) of the National Statistical Service of Greece (E.S.Y.E).
\end{abstract}

Keywords: Food expenditure, Seasonality of food consumption, Alimentary patterns

\section{Introduction}

The present work is descriptive in nature and does not deal with the theorization and justification of the development of alimentary consumption in Greece. Our focus is exploratory in an attempt to examine the annual seasonality patterns of food expenditure in the post war period (1957 to 2005). On these grounds we find major changes in dietary behaviour; traditional food consumption based on the Mediterranean alimentation is gradually declining in favour of industrial and post-industrial dietary consumption trends (Sotiropoulos et al. 2009, 2010). In traditional alimentation food consumption exhibited considerable differences during the four seasons of the year. In the summer months, patterns conformed to Mediterranean dietary characteristics, whereas in wintertime they followed international-industrialised features. With the decline of traditional alimentation these differences are being ameliorated; contemporary (post)industrial-international dietary trends prevail now in all seasons throughout the year.

\section{Method}

For the purposes of our analysis the qualitative formula describing alimentary consumption from Sotiropoulos (2006) was used:

$\mathrm{Q}_{\text {alimentary pattern }}=\left(\mathrm{Q}_{\text {plant components }}, \mathrm{Q}_{\text {animal components }}, \mathrm{Q}_{\text {agricultural components, }}, \mathrm{Q}_{\text {industrial components, }}\right.$ Q biological components)

The above formula is derived from:

$\mathrm{CM}_{\mathrm{d}}=\left(\mathrm{Ch}_{\mathrm{n}}, \mathrm{Ch}_{\mathrm{t}}\right)$

where: $\mathrm{CM}_{\mathrm{d}}$ denotes the description of the consumption pattern; $\mathrm{Ch}_{\mathrm{n}}$, the natural features; and $\mathrm{Ch}_{\mathrm{t}}$, the technical features. Formula (2) describes the qualitative interrelation of consumption of all goods and services (See Sotiropoulos and Frangos 2009).

Due to a lack of research in seasonality patterns of alimentary consumption in Greece our work draws on the 
general principles of economic analysis of consumption discussed by Lancaster (1966). Data were sourced out from Household Budget Surveys of the National Statistical Service of Greece (H.B.S. 1957/58, 1963/64, 1974, $1981 / 82,1987 / 88,1993 / 94,1998 / 99,2004 / 05)$ that record food consumption quarterly. There is a lack of consistency in the original sources in data groupings in formal seasonal classes (e.g spring, summer, etc.). Nevertheless seasonal analysis is possible if we break down and re-synthesise the original groupings in accordance to the constituent months of every quarter and season respectively. In addition the data of the last four Household Budget Surveys (H.B.S. 1981/82, 1987/88, 1998/99 and 2004/05) are only slightly different from the preceding three (H.B.S. 1957/58, 1963/64, 1974) and H.B.S. of 1993/94 in terms of the associated month groupings.

\section{Traditional and Contemporary Patterns of Alimentation}

\subsection{Traditional alimentation}

According to Sotiropoulos and Demousis (2002) there was a predominance of plant-based agricultural products in the traditional dietary patterns of the early '50s in Greece (cereals, fruits and vegetables, legumes, the traditional bean-soup, olive oil, and wine). Subsequently in the 60s there was a rapid increase in the consumption of red meat and processed food, resulting to the complete reversal of the "Mediterranean" diet (Renaud 1995) and the prevalence of the international (of western origin) - industrialised one.

The traditional features of the Mediterranean diet (see table 3.1) as well as the consumption of plant-based agricultural products (vegetables and fruits) stood out during the spring and summer months. During these months they had their highest values of consumption if compared with the mean values for the total population. In contrast consumption of animal-based food (meat, fish, fats and oils) increased during autumn and in wintertime and it was at its highest levels then if compared with the mean values of the total population. A similar note is made for confectionery products.

In this decade consumption of industrial-processed food and of food away-form-home also increased (restaurants - traditional cafes). In the above table these costs were included under the category of "other food", and the associated expenditure was also higher during spring and summer and lower during autumn and winter. Again during the summertime consumption in this category was higher than the mean positions of the total population.

Finally dairy consumption was increased during the winter and spring months and decreased during summer and autumn. Winter and spring are the production periods for fresh milk (sheep, goat) and they coincide with the higher consumption levels. The opposite applies for summer and autumn.

From the above, seasonality of consumption in traditional alimentation appears to follow the seasonality of food production. However these patterns diminish over the years as food expenditure decreases as a percentage of total spending.

\subsection{Western origin - industrialised alimentary patterns}

Seasonality intensity diminished after the 50s (table 3.2). Spending on cereals went up during winter and spring. A similar increased intake was shifted in spring and in summer for confectionery food, whereas in dairy products the whole pattern of the previous decades was overturned with increased consumptions during the winter. There was increased expenditure on food away form home and on non-alcoholic beverages both in spring and summer with the same applying for meat and fish protein, whereas olive oil and other fat based food were mainly consumed during winter. Non-alcoholic beverages, vegetables and fruits continued to follow the previous decades' dietary habits.

Alimentary expenditure as a percentage of total consumption costs continued to decline. More specifically, alimentation away from home and spending on non-alcoholic beverages increased as percentages of total alimentation. Meat consumption decreased (if compared with the H.B.S. of the 80s and 90s), and cereal intake remained stable. The above observations appear to support our opinion that there was a weakening of the seasonality patterns that traditional alimentation demonstrated. A substitution with contemporary industrial (with adding-value food processing methods) trends took place.

\subsection{Seasonal features and evolution of the industrialisation of alimentary behaviour}

The "westernisation" of the traditional diet during the post-war era (tables 3.3 and 3.4) was characterised by different seasonal intensity and qualities. During winter there was increased spending on industrialised-processed food, and amplified consumption of rural products during the summer. This until the 70s; thereafter (with the exception of H.B.S. of 2004/05) spending on processed food as a percentage of total alimentation costs has increased during spring and summer and declined during winter. These observations also provide indications 
towards a weakening of the seasonal patterns of food consumption.

After the 70s (and especially after the 80s) there has been increased expenditure on rural food products during the autumn and winter. A similar observation can also be made for the traditional categories of "lamb and kid" and legumes. These seem again to annul any existing seasonal realities. Increased consumption of lamb and kid meat was noticed (in the 50s and 60s) during Christmas and Easter that coincided with the production period and the wider religious, cultural and historical parameters of Greece and the general Mediterranean area. After the 70 s with the general refrigerator usage and other modern food preservation techniques there has been an increase of related expenditure during the summertime (but also during spring in the latest H.B.S. of 2004/05).

Increased spending trends in legumes were taking place in autumn (soon after the harvesting period) and not in spring or during the summers. Dry beans and lentils are not considered as appropriate for consumption in the hot Mediterranean summers in contrast to frozen peas for example. However these alimentary patterns changed after the 70s (with the exception of the latest H.B.S. of 2004/05).

Finally expenditure on food away from home in the Mediterranean patterns was mainly taking place in traditional cafes (kafenia) rather than in restaurants during the summer time and especially in spring. Food spending in restaurants on the other hand was increased in autumn and winter. In the last two decades there has been a weakening of the seasonal differentiations also in this category with a proportional increase of the associated expenditure in restaurants in winter and a decrease in autumn. In the last H.B.S. (2004/05) there was a complete reversal of the above pattern with a high proportion of spending in restaurants throughout the year and especially during autumn. Nowadays this has become a mainstream trend linked according to H.B.S. data with the predominance of the industrialised patterns of alimentary consumption in the country and a spreading of new forms of restaurants (such as fast food) instead of the traditional ones (brasseries, taverns, etc.)

\section{Conclusions}

Our main observation in this study is that food consumption in the summer appears to relate to away-from home expenditure and plant-based food. On the other hand during wintertime alimentation is supported by animal-based and processed food products. These remarks seem to apply for the entire period of this study, regardless of the predominant form of alimentation of each era (traditional Mediterranean or international-industrialised).

This general observation could become the basis for future research on international grounds; for example examining the dietary habits of the southern populations (referred as "bread-eaters" by Homer as cited by Montanari 1993) compared to those of northern populations (characterised as meat-eaters, see Montanari 1993). A hypothesis could be formed ceteris paribus as: Cold weather conditions: animal-based food; warm climates: plant-based food.

We also noticed a weakening of the seasonal patterns of alimentation throughout the sample period of our study. This applies to all categories of food products regardless of their natural characteristics (plant or animal-based, industrial or agricultural). In this manner consumption behaviour, spreads out in all the four seasons of the year and it stops depending on the natural annual production cycle (as in traditional societies); food consumption condenses on two axes (winter and summer). This pattern first appeared after the 1960s and further research is needed to examine potential factors that fed that change.

\section{References}

E.S.Y.E. (1957 - 2005). Household Budget Surveys (H.B.S.). The National Statistical Service of Greece (E.S.Y.E). Athens. Greece.

Lancaster K. (1966). A New Approach to Consumer Theory. Journal of political economy, 74: 132 - 157.

Montanari M. (1993). La Fame e l'Abbondanza. Storia dell' Alimentazione in Europa, ed. G. Laterza \& Figli, Roma.

Renaud S. (1995). Le régime santé. Ed. Odile Jacob, Paris.

Sotiropoulos I., \& Frangos C. C. (2009). A new approach to the description of alimentary consumption patterns: The case of Greece. Paper presented in the $2^{\text {nd }}$ International Conference of Quantitative and Qualitative Methodologies in the Economic and Administrative Sciences. TEI of Athens. Greece. Proceedings, pp 421-427.

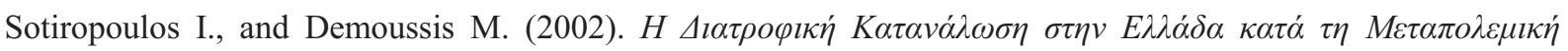

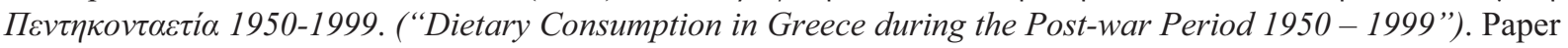
presented in the 7th Panhellenic Conference of ETAGRO, proceedings, pp. 457-459. 
Sotiropoulos I., Georgakopoulos G., and Kyritsis K. (2010). Globalisation of the Alimentary Consumption Patterns in Greece (1957 to 2005); an Economic Analysis. International Journal of Economics and Finance, 2(1): $120-130$.

Sotiropoulos I., Georgakopoulos G., and Salavrakos I. D. (2009). Alimentary Expenditure of the Different Socio-Vocational Classes of the Population in Greece (1957-2005): A Description of the Dietary Models. International Business Research, 2(3): 17 - 27

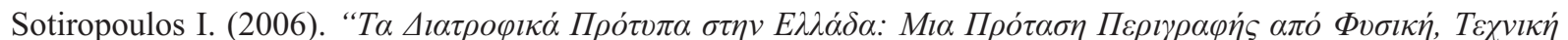

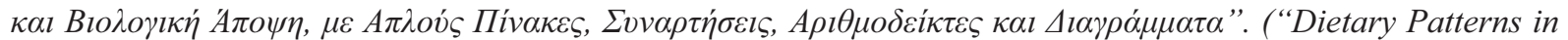
Greece: a Descriptive Suggestion of Their Natural, Technical and Biological Characteristics Using Simple Tables, Qualitative Formulas, Ratios and Charts"). Paper presented in the 19th Panhellenic Statistical Conference. The Statistical Institute of Greece (E.S.I.). Greece. Proceedings, pp 457-463.

Table 3.1. Alimentary Expenditure (mean values per quarter) in \%

\begin{tabular}{|r|l|r|r|r|r|r|}
\hline & Quarter & \multicolumn{2}{l|}{$\begin{array}{l}\text { Apr. } \\
\text { Jun. 1957 }\end{array}$} & $\begin{array}{l}\text { Jul. } \\
\text { Sept. 1957 }\end{array}$ & $\begin{array}{l}\text { Oct. } \\
\text { Dec. 1957 }\end{array}$ & $\begin{array}{l}\text { Jan. } \\
\text { Mar. 1958 }\end{array}$ \\
\hline 1 & Cereal & 15,5 & 15,3 & 15,9 & 15,6 & 15,6 \\
\hline 2 & Meat & 15,5 & 14,7 & 17,5 & 16,6 & 16,1 \\
\hline 3 & Fish & 5,0 & 4,8 & 5,6 & 5,9 & 5,3 \\
\hline 4 & Oils & 10,5 & 10,5 & 12,5 & 10,9 & 11,1 \\
\hline 5 & Dairy & 13,0 & 11,2 & 11,3 & 13,0 & 12,1 \\
\hline 6 & Vegetables and Fruits & 18,0 & 20,5 & 17,3 & 16,2 & 17,9 \\
\hline 7 & Confectionery & 6,5 & 4,8 & 7,1 & 7,1 & 6,4 \\
\hline 8 & Other Food & 16,1 & 18,1 & 12,8 & 14,6 & 15,3 \\
\hline & Alimentation & 100 & 100 & 100 & 100 & 100 \\
\hline & Alimentation / & 42,0 & 42,8 & 39,0 & 39,4 & 40,6 \\
\hline
\end{tabular}

Note: H.B.S. of 1957/58 was conducted for the urban households, whereas H.B.S. of 1963/64 for the rural ones. All other "Household Budget Surveys" where conducted for the total of the households in the country

Source: ESYE, H.B.S. 1957/58.

Table 3.2. Alimentary Expenditure (mean values per quarter) in \%

\begin{tabular}{|c|c|c|c|c|c|c|}
\hline & Quarter & $\begin{array}{l}\text { Feb - Apr. } \\
2004\end{array}$ & $\begin{array}{l}\text { May - Jul } \\
2004\end{array}$ & $\begin{array}{l}\text { Aug - Oct } \\
2004\end{array}$ & $\begin{array}{l}\text { Nov - Jan } \\
2005\end{array}$ & $\begin{array}{l}\text { Whole } \\
\text { Year }\end{array}$ \\
\hline 1 & Cereal & 8,4 & 8,0 & 8,3 & 9,7 & 8,6 \\
\hline 2 & Meat & 14,8 & 13,1 & 14,4 & 15,4 & 14,4 \\
\hline 3 & Fish & 6,2 & 4,3 & 5,0 & 6,1 & 5,4 \\
\hline 4 & Oils & 3,3 & 3,4 & 3,5 & 4,2 & 3,6 \\
\hline 5 & Dairy & 11,1 & 11,8 & 12,3 & 12,8 & 12,0 \\
\hline 6 & Vegetable & 8,3 & 7,5 & 6,9 & 7,4 & 7,5 \\
\hline 7 & Fruit & 4,6 & 5,1 & 4,7 & 5,4 & 4,9 \\
\hline 8 & Confectionery & 4,7 & 4,2 & 4,0 & 4,0 & 4,2 \\
\hline 9 & Food away from home & 34,2 & 37,9 & 36,3 & 30,3 & 34,7 \\
\hline 10 & Non alcoholic beverages & 3,5 & 4,1 & 3,8 & 3,7 & 3,7 \\
\hline \multirow[t]{3}{*}{11} & Other food & 0,9 & 0,7 & 0,8 & 1,0 & 0,9 \\
\hline & Alimentation & 100 & 100 & 100 & 100 & 100 \\
\hline & $\begin{array}{l}\text { Alimentation/ } \\
\text { Consumption (\%) }\end{array}$ & 25,3 & 26,4 & 26,5 & 26,6 & 26,2 \\
\hline
\end{tabular}

Source: ESYE, H.B.S. 2004/05 
Table 3.3. Detailed expenditure structure for cereal, meat, vegetables-legumes, and food away from home during spring and summer, in \%

\begin{tabular}{|l|r|r|r|r|r|r|}
\hline & \multicolumn{7}{|l|}{ Spring } & \multicolumn{2}{l|}{ Summer } \\
\hline H.B.S.: & $1963 / 64 *$ & $1981 / 82$ & $2004 / 05$ & $1963 / 64$ & $1981 / 82$ & $2004 / 05$ \\
\hline Bread - cereal & & & & & & \\
\hline Bread & 31,8 & 55,3 & 50,5 & 41,8 & 51,2 & 52,9 \\
\hline Cereal & 23,9 & 5,7 & 4,6 & 18,1 & 9,4 & 3,5 \\
\hline Industrial (processed) cereal & 16,4 & 30,5 & 39,1 & 15,0 & 31,9 & 41,6 \\
\hline Rice & 11,2 & 8,5 & 5,8 & 11,1 & 7,6 & 6,0 \\
\hline Other cereal & 16,6 & - & - & 14,1 & - & - \\
\hline Meat & & & & & & \\
\hline Veal & 11,4 & 45,7 & 34,3 & 23,7 & 37,6 & 44,0 \\
\hline Lamb and kid & 35,9 & 12,8 & 26,3 & 26,0 & 31,7 & 7,8 \\
\hline Processed meat & 2,4 & 7,5 & 10,5 & 2,2 & 5,9 & 11,1 \\
\hline Legumes-vegetables & & & & & & \\
\hline Legumes & 12,7 & 15,7 & 6,6 & 9,9 & 11,2 & 3,9 \\
\hline Fresh vegetables** & 61,1 & 50,3 & 54,3 & 77,0 & 52,3 & 63,8 \\
\hline Industrial (processed) vegetables & - & 6,7 & 16,8 & - & 9,9 & 12,0 \\
\hline Potatoes & 26,2 & 27,3 & 17,7 & 13,0 & 26,6 & 15,9 \\
\hline Food away from home & & & & & & \\
\hline Restaurants & 29,3 & 49,6 & 52,0 & 34,9 & 50,0 & 52,1 \\
\hline Traditional cafes (kafenia) & 70,7 & 50,4 & 48,0 & 65,1 & 50,0 & 47,9 \\
\hline
\end{tabular}

* Data from H.B.S. of 1963/64 were used since seasonal information from H.B.S. of 1957/58 on a per food product class was not detailed.

** (including tomato-paste) in H.B.S. of 1963/64.

Source: ESYE, H.B.S. 1963/64, 1981/82, 2004/05.

Table 3.4. Detailed expenditure structure for cereal, meat, vegetables-legumes, and food away from home during autumn and winter, in $\%$.

\begin{tabular}{|l|r|r|r|r|r|r|}
\hline & \multicolumn{2}{|l|}{ Autumn } & \multicolumn{1}{l|}{ Winter } \\
\hline H.B.S.: & $1963 / 64$ & $1981 / 82$ & $2004 / 05$ & $1963 / 64$ & $1981 / 82$ & $2004 / 05$ \\
\hline Bread - cereal & & & & & & \\
\hline Bread & 29,3 & 58,0 & 52,7 & 21,8 & 55,1 & 47,3 \\
\hline Cereal & 33,3 & 6,7 & 3,4 & 22,1 & 8,2 & 4,3 \\
\hline Industrial (processed) cereal & 19,9 & 27,0 & 37,6 & 19,0 & 28,8 & 42,6 \\
\hline Rice & 11,9 & 8,3 & 6,4 & 10,2 & 7,9 & 5,9 \\
\hline Other cereal & 5,6 & - & - & 26,9 & - & - \\
\hline Meat & & & & & & \\
\hline Veal & 20,0 & 50,9 & 43,7 & 12,8 & 46,2 & 27,0 \\
\hline Lamb and kid & 14,8 & 14,7 & 6,9 & 41,6 & 17,3 & 9,9 \\
\hline Processed meat & 5,9 & 5,8 & 12,8 & 3,9 & 6,4 & 12,4 \\
\hline Legumes - vegetables & & & & & & \\
\hline Legumes & 28,5 & 3,2 & 6,1 & 31,2 & 9,1 & 10,3 \\
\hline Fresh vegetables** & 46,3 & 74,5 & 59,9 & 35,8 & 61,8 & 52,3 \\
\hline Industrial (processed) vegetables & - & 3,1 & 14,1 & - & 5,2 & 17,5 \\
\hline Potatoes & 25,2 & 19,2 & 15,0 & 33,1 & 24,0 & 15,9 \\
\hline Food away from home & & & & & & \\
\hline Restaurants & 36,5 & 54,1 & 54,2 & 40,5 & 52,5 & 50,1 \\
\hline Traditional cafes (kafenia) & 63,5 & 45,9 & 45,8 & 59,5 & 47,5 & 49,9 \\
\hline
\end{tabular}

* Data from H.B.S. of 1963/64 were used since seasonal information from H.B.S. of 1957/58 on a per food product class was not detailed.

** (including tomato-paste) in H.B.S. of 1963/64.

Source: ESYE, H.B.S. 1963/64, 1981/82, 2004/05. 